природних систем. Означена проблема повинна звучати не лише на навчальних заняттях, але й на студентських наукових конференціях, у статтях здобувачів вищої освіти, зокрема у «Студентському віснику НУ ВГП». Корисною вважаємо практичну екологічну діяльність - толоки з очищення територій та водоймищ від сміття, роздільне сортування сміття тощо.

Перспективними напрямами подальших досліджень щодо вдосконалення екологічної підготовки вважаємо розгляд питань про поєднання екологічної освіти, екологічного виховання та еколого-практичної діяльності.

\section{СПИСОК ВИКОРИСТАНОЇ ЛІТРАТУРИ}

1. Андрущенко В. П. Екологічна політика і освіта: проблеми становлення / В. П. Андрущенко // Роздуми про освіту: статті, нариси, інтерв'ю. - К. : Знання України, 2004. - С. 253-258.

2. Байрамова О. В. Екологічна освіта в морських вищих навчальних закладах: теоретичний аспект / O. В. Байрамова // Science and Education a New Dimension: Humanities and Social Sciences, Budapest. 2017. - V (20), Issue: 120. - P. 45-49.

УДК 37.091.4

DOI: $10.37026 / 2520-6427-2019-99-3-148-152$
3. Буденкова Н. М. Застосування активних методів навчання у формуванні довершеної особистості / Н. М. Буденкова, О. І. Мисіна // Науковий журнал «Молодий вчений». - 2018. - № 4.1 (56.1), квітень. - С. 1-5.

4. Концепція екологічної освіти України // Екологія і ресурси. - 2002. - № 4. - С. 5-25.

5. Курняк Л. М. Екологічне виховання студентів ВНЗ / Л. М. Курняк, О. А. Курняк // Збірник наукових праць Хмельницького інституту соціальних технологій Університету «Україна». - 2012. - № 5. C. $109-114$.

6. Постанова Кабінету Міністрів України від 25.03.1999 № 465 «Правила охорони поверхневих вод від забруднення зворотними водами» [Електронний ресурс]. URL: https://zakon.rada.gov.ua/laws/ show/465-99-\%D0\%BF (дата звернення: 18.05.2019).

7. Посторонко А. І. Про стан екологічної підготовки інженерних та інженерно-педагогічних фахівців хімічного профілю / А. І. Посторонко // Гуманізація навчально-виховного процесу : наук.-метод. зб. / Слов'ян. держ. пед. ун-т. - Слов'янськ, 2006. Вип. 32. - С. 3-10.

Дата надходження до редакиї: 22.05.2019 p.

\section{Надія КАЛІНІЧЕНКО,}

докторка педагогічних наук, професорка, заслужена вчителька України,

завідувачка кафедри біології та методики ї̈ викладання Центральноукраїнського державного педагогічного університету імені Володимира Винниченка,

м. Кропивницький

\title{
УПРОВАДЖЕННЯ ІДЕЙ ВАСИЛЯ СУХОМЛИНСЬКОГО В ОСВІТНІЙ ПРОСТІР НОВОЇ УКРАЇНСЬКОЇ ШКОЛИ
}

У статті аналізуються актуальні ідеї Василя Сухомлинського з метою їх упровадження в освітній простір Нової української школи, иляхи та умови формування фахової компетентності в майбутніх учителів природничих спеціальностей на основі гуманістичної педагогіки. Висвітлюється авторська позииія щчодо оптимізації даного процесу на національному та регіональному рівнях.

Ключові слова: актуальні ідеї Василя Сухомлинського, Нова українська школа, освітній простір, майбутні вчителі біології, фахова компетентність, педагогічна творчість.

В статье анализируются актуальные идеи Василия Сухомлинского с иелью их внедрения в образовательное пространство Новой украинской школь, пути и условия формирования профессиональной компетентности у будущих учителей естественных специальностей на основе гуманистической педагогики. Освещается авторская позиция по оптимизации данного прочесса на национальном и региональном уровнях.

Ключевые слова: актуальные идеи Василия Сухомлинского, Новая украинская школа, образовательное пространство, будущие учителя биологии, профессиональная компетентность, педагогическое творчество.

The article deals with the current ideas of Vasyl Sukhomlinsky with a view to their introduction into the educational space of the New Ukrainian School, ways and conditions of formation of professional competence in future teachers of natural sciences based on humanistic pedagogy. 
Students'perception of Sukhomlinsky's assertion that the teacher's creative research contributes to the study of the facets of the pedagogical process; a radical change in the teacher's view of his own work; the formation of the creative personality of the student, that is, the implementation of the psychological and pedagogical idea of human design. It inspires the work of future teachers, makes it meaningful, purposeful, rich with innovative pursuits and discoveries.

Content models, lessons learned, conclusions and recommendations are model lessons, creative educational and research projects, coursework and qualifications. The role of practical studying of the experience of creatively working educators in forming the skills of using the interactive methodology of teaching biology, providing differentiation and psychologization of the educational process aimed at improving methods, techniques and means of forming and controlling the knowledge of students in biology, development of subject subjects that provides them with self-development, develops skills of self-analysis, self-control and self-esteem.

It has been highlighted author's position on the optimization of this process at national and regional levels.

Key words: current ideas of Vasyl Sukhomlinsky, New Ukrainian School, educational space, future biology teachers, professional competence, pedagogical creativity.

Постановка проблеми. Концепцією Нової української школи передбачається оновлення змісту освіти, заснованого на формуванні компетентностей, потрібних для успішної самореалізації в суспільстві, нова структура школи, яка дасть змогу добре засвоїти новий зміст і набути компетентності для життя, умотивований учитель, який має свободу творчості й розвивається професійно, сучасне освітнє середовище, яке забезпечить необхідні умови, засоби і технології для навчання учнів, освітян, батьків не лише в приміщенні навчального закладу [1, с. 2]. Метою Концепції є забезпечення проведення системної реформи загальної середньої освіти на основі нового принципу педагогіки партнерства, що грунтується на співпраці учня, вчителя і батьків. Законом України «Про освіту» компетентність потрактована «як динамічна комбінація знань, способів мислення, поглядів, цінностей, навичок, умінь, інших особистих якостей, що визначає здатність особи успішно провадити професійну та/або подальшу навчальну діяльність», а ключові компетентності мають включати здатності забезпечити особисту реалізацію та життєвий успіх протягом усього життя [2, с. 4 ]. Уже сьогодні на ринку праці затребувані фахівці, які вміють ставити цілі та досягати їх, працювати в команді, спілкуватися в багатокультурному середовищі, бачити власну перспективу розвитку та розвитку освітнього закладу. Передбачається, що здійснювані освітні реформи матимуть суттєвий вплив на розвиток економіки та сприятимуть конкурентоспроможності української освіти на міжнародному рівні [3-5].

Ми переконані, що окреслені освітні реформи можна успішно розв'язувати шляхом осмислення, узагальнення, оцінки та використання досвіду минулого як потужного джерела ідей для розбудови української освіти.

Вирішуючи проблеми сьогодення в педагогічній праці, ми знову звертаємось до педагогічних ідей і педагогічної спадщини видатного Учителя Василя Сухомлинського, 101 річницю від дня народження якого цьогоріч відзначає педагогічна громадськість, оскіль- ки його наукова спадщина є актуальною в контексті сучасної дійсності, навчає нас добру, людяності, милосердю, подвижництву, новому філософському усвідомленню місії школи і освіти, в іiі основі наука, майстерність і мистецтво, визнання іiі дієвості педагогами країн світу. Відзначаючи значимість діяльності та педагогічної спадщини Павлиського Учителя 39-та сесія Генеральної конференції ЮНЕСКО затвердила рішення про відзначення у 2018 році на рівні ЮНЕСКО 100-річчя від дня народження Василя Сухомлинського.

Аналіз наукових досліджень і публікацій. Значний внесок у вивчення та популяризацію наукового доробку В. О. Сухомлинського зробили вчені М. Антонець, Н. Гупан, Н. Дічек, І. Бех, А. Богуш, Л. Березівська, Л. Бондар, І. Богуславський,. А. Зязюн, В. Кузь, А. Луцюк, Лі Цзіхуа, В. Риндак, О. Савченко, О. Сухомлинська, М. Ярмаченко та ін.

Метою статті $\epsilon$ актуалізація провідних гуманістичних концептів педагогіки В. О. Сухомлинського для формування освітнього середовища Нової української школи.

Виклад основного матеріалу. Орієнтація на потреби учня в освітньому проиесі, дитиноцентризм. Учителя Сухомлинського у взаєминах з учнями характеризувала духовна єдність; він був для них керівником, наставником, другом і зберегли вони ці почуття впродовж усього життя. Він умів покоління учнів зробити щасливими, дарував їм радість, пізнання наукових основ навчальних предметів (щоб були освіченими), радість творчості (щоб були успішними; понад 40 гуртків, студій, наукових товариств діяли в школі), радість праці - адже територія школи була ними перетворена в найкраще місце селища; краса природи захоплювала і підводила вихованців до розуміння вищої краси - краси людини, іiі праці, вчинків і життя.

Педагог теоретично обгрунтував і практично реалізував розроблені ним принципи виховання шкільного колективу, які базуються на тривалому педагогічному досвіді Павлиської середньої школи.

Наскрізний прочес виховання, який формує иінноcmi. Ідейність. У цілях колективу, вважав педагог, повинні відбиватися всенародні інтереси. Ця єдність на уроках, позакласних заняттях, - першоджерело й найважливіший стимул формування стійких ідейних переконань колективу й кожної особистості.

Єдність ідейної та організаційної основ шкільного колективу. Це спільна діяльність учнівських і учительських організацій, передача життєвого досвіду і духовних надбань представниками старшого покоління поколінню молодому.

Керівна роль педагога. Колектив як виховна сила існує лише тому, що наявна спрямовуюча мудрість старших товаришів, керівника школи, які одухотворюють колектив моральним багатством, інтелектуальною багатогранністю, життєвою мудрістю, добре знають психічні, духовні, інтелектуальні особливості кожної дитини.

Багатство відносин між учнями $і$ педагогами, між учнями, між педагогами. Єдність дій, багатогранне переплетення інтересів вихователів і вихованців, спільне задоволення духовних потреб, взаємне збагачення і постійна передача духовних багатств - це неодмінні риси шкільного колективу. В школі дитина не лише вчиться, наголошував педагог, у школі вона живе. Школа, як магніт, мусить притягувати учнів своїм цікавим, змістовним життям. Лише за цієї умови й навчання може притягувати, як магніт. 
Яскраво виражена громадянська сфера духовного життя вихованців і вихователів. Учитель і учні повинні зустрічатися не тільки в класі: школяр за партою (він здобуває знання, відповідає на запитання вчителя, одержує оцінки), педагог - за вчительським столом (він дає знання, ставить запитання учневі, виставляє оцінки). Якщо є тільки ця сфера відносин, то шкільного колективу як виховної сили не може бути. Учитель і учень мають діяти разом і як двоє громадян - лише за цієї умови вони можуть бути в повному розумінні вихователем і вихованцем. Шкільне життя має бути таким, щоб у ньому завжди діяла система відповідальності людини за людину, відповідальності людини перед суспільством.

Самодіяльність, творчість, ініиіатива як особливі грані виявлення різноманітних відносин між членами колективу. Сухомлинський застерігає: самодіяльність - не стихія. Без цілеспрямованого й ідейного, педагогічного, батьківського керівництва в колективі справжня самодіяльність неможлива. Тільки за умови, що кожен член колективу є активним учасником процесу виховання, можливі справжні самодіяльність, творчість, ініціатива.

Постійне примноження духовних багатств, особливо ідейних та інтелектуальних. Повнокровне, різноманітне інтелектуальне життя шкільного колективу - важлива ділянка виховної роботи. Від того, що думають вихованці, які інтереси їх хвилюють, як утверджується й розвивається потреба в знаннях, яке місце в житті колективу посідають відносини, засновані на інтелектуальному спілкуванні, залежить дух шкільного життя, виховна сила колективу.

Гармонія високих, благородних інтересів, потреб $i$ бажань. Виховна сила шкільного колективу значною мірою залежить від того, які інтереси й духовні потреби виховують у школярів і чи гармонують вони із бажаннями, особливо підлітків і юнаків-старшокласників. Гармонія у вихованні колективу досягається лише за тих умов, коли бажання людини виростають і утверджуються на грунті високоморальних, розумових інтересів і потреб. Якщо в колективі панує розважальна спрямованість, духовне життя підлітків, особливо юнаків і юнок, стає убогим, обмеженим.

Створення $i$ дбайливе збереження традицій, передача їх від покоління до покоління як духовного надбання. Традиції, вважав Василь Олександрович, можна порівняти зі скарбничкою, куди кожне покоління кладе свій маленький коштовний внесок. Із маленьких крихіток складаються великі скарби. Велике мистецтво й майстерність, гаряче серце й холодна мудрість потрібні для того, щоб ці скарби не розтринькувалися, а вміло використовувалися в духовному житті наступних поколінь, дбаючи про збагачення скарбнички новими коштовностями.

Ідейне, інтелектуальне, естетичне багатство взаємовідносин між шкільним колективом та інши ми колективами сочіуму. Важливим чинником виховання є згуртованість людей у колектив на основі єдності мети, праці, діяльності. У шкільного колективу має бути духовно багатий ідейний однодумець - колектив трудівників, які беруть безпосередню участь у творенні матеріальних і духовних цінностей нашого суспільства, трудівників, для яких праця в ім'я суспільного блага є змістом їхнього життя.

Емоиійне багатство колективного життя. У практичній роботі колектив школи прагне, щоб завдяки багатству життя колективу кожен його член переживав найвищу людську радість - радість творення для людей, постійного нагромадження внутрішніх духовних багатств, радість усвідомлення, що тебе шанують і поважають люди.

Сувора дисиипліна і відповідальність особистості за свою пращю, поведінку. Однією з граней педагогічної майстерності $є$ вміння створити в колективі такі взаємовідносини, щоб кожна людина дорожила честю колективу, розуміла й відчувала, що таке - можна, не можна, треба. Ми вважаємо, зазначав Василь Сухомлинський, дуже важливим створити такі трудові, товариські, творчі обставини в колективі, за яких би людина ставила вимоги сама перед собою, відчувала відповідальність перед суспільством і на цій основі розуміла відповідальність перед власним сумлінням [8; 9].

Ідея успіху в розвитку дитини - пріоритетна у педагогічній концепції Василя Сухомлинського, адже має живильне коріння: народну педагогіку, прогресивну педагогіку минулого, здобутки сучасної психолого-педагогічної науки. Енциклопедичні знання, зокрема іноземних мов, освіченість, інтелігентність, дивовижна працьовитість мають бути для нас мотивацією, аби краще пізнати Педагога-Гуманіста. Його педагогічна система збагатила світову педагогічну науку - як теорію, так і практику - новаторськими ідеями і положеннями. Він мав не лише педагогічний, а й літературний талант - залишив нам у спадок 48 книг, понад 1500 творів для дітей, 500 чудових статей, велику рукописну спадщину. Праці Вчителя перекладені на 56 мов світу.

Саме усвідомлення ідей гуманної педагогіки дозволяє педагогам долучатися до перспективних проєктів, зокрема «Шкільний учитель нового покоління», «Сучасні заклади освіти», до успішного використання електронних засобів навчання, мультимедійних навчальних програм, аудіовізуального обладнання, нового обладнання шкільних кабінетів. Інститут післядипломної педагогічної освіти імені Василя Сухомлинського (м. Кропивницький) із метою розвитку професійних компетентностей пропонує вчителям різні форми роботи в міжкурсовий період: конкурси, семінари, школи професійної майстерності, майстер-класи, педагогічні студії, творчі лабораторії, авторські творчі майстерні, інтернет-конференції, тренінги, творчі групи.

Користуються визнанням щорічні Всеукраїнські науково-практичні конференції з актуальних проблем сухомлиністики: виховання громадянина-патріота, розвиток дидактичних ідей, мистецтво сучасного менеджменту, розвиток творчої особистості. Більше двадцяти років педагогічний інститут, нині університет, проводить щорічні Всеукраїнські студентські науково-практичні конференції з проблем використання педагогічної спадщини відомого педагога для формування шкільного середовища, розвитку творчого вчителя і створення оптимальних умов для розвитку вихованців. Сухомлинський наголошував, що лише творча особистість учителя зможе виховувати. «Ми маємо справу 3 найскладнішим, неоціненним, найдорожчим, що є в житті, - $з$ людиною» [7, с. 5].

«Педагогічна творчість» Василем Сухомлинським потрактована як уміння педагога глибоко проникати в теоретичний зміст педагогічного явища, осмислювати його, оскільки успішна педагогічна праця неможлива без елементів дослідження [6, с. 461].

На основі педагогічних концептів Учителя викладачі кафедри біології на лекціях, практичних та семінарських заняттях, під час навчальних та педагогічних практик навчають майбутніх учителів освітньої галузі «Природознавство» відкривати 
по новому проблеми, які розв'язані педагогічною наукою, творчо працювати, аналізувати навчальні ситуації, прогнозувати розвиток подій. Актуальною залишається порада В. О. Сухомлинського розпочинати педагогічне дослідження зі спостереження, вивчення та аналізу фактів, тобто усвідомлення реальної сутності, виокремлення взаємозалежностей: а) того, що дає саме життя (дитина приходить до школи з об'єктивно наявними рисами); б) того, що робить учитель; в) того, що буде досягнуто. Це допомагає майбутнім учителям формувати вміння розуміти сутність педагогічного явища, що робить працю вчителя творчим процесом. Дозволяє, спостерігаючи, вивчаючи, аналізуючи факти, активно впливати на педагогічне явище, творити його, здійснювати передбачення як найважливіший елемент творчого дослідження. «Бачення нових сторін, нових рис, нових деталей у звичайному ... - це важлива умова творчого ставлення до роботи» [6, с. 473$]$.

Майбутні вчителі сприймають твердження В. О. Сухомлинського, що творче дослідження вчителя сприяє: а) вивченню граней педагогічного процесу; б) докорінній зміні погляду вчителя на власну роботу; в) формуванню творчої особистості школяра, тобто реалізації психолого-педагогічної ідеї проєктування людини. Це одухотворює працю майбутніх учителів, робить іiі осмисленою, цілеспрямованою, насиченою інноваційними пошуками і відкриттями. Змістовними, сповненими власними дослідженнями, висновками та рекомендаціями стають моделі уроків, творчі навчальні та дослідницькі проєкти, курсові та кваліфікаційні роботи, адже В. О. Сухомлинський переконував, що «... найголовнішою сферою єднання теорії і практики є проєктування людини» [6, с. 605], створення людини, здатної стати активною творчою силою сьогодні й у майбутньому. Інноваційна поведінка і креативність майбутнього педагога формуються під впливом освітнього середовища з високим ступенем невизначеності й потенційною багатоваріантністю (багатство можливостей). Якщо невизначеність стимулює пошук власних орієнтирів, то багатоваріантність забезпечує можливість їх знаходження. Майбутні вчителі усвідомлюють необхідність інноваційної діяльності, потребу в готовності до творчої діяльності щодо нововведень в освітньому закладі, здатності до фахової рефлексії.

Студенти долучаються до творчих пошуків педагогів, які мають продуктивні результати, відзначаючи при цьому роль керівників освітніх установ 3 інноваційним потенціалом у реалізації завдань Нової української школи, зокрема забезпечення достатнього наукового і практичного рівня підготовки вчителя 3 дослідницьких технологій, а також створення в колективі комфортного психологічного клімату, умов праці, належного рівня шкільної культури та матеріальної і моральної мотивації діяльності педагогів.

При оцінці творчої лабораторії вчителя використовується ряд критеріїв, серед яких - актуальність, новизна, результативність, стабільність, перспективність. Наприклад, на сьогодні актуальними є проблеми вдосконалення змісту, форм, методів навчання і виховання учнів, використання особистісно орієнтованих технологій, формування національної свідомості школярів, реалізація завдань допрофільного і профільного навчання тощо. Базою виробничих практик для майбутніх учителів біології $\epsilon$ кращі навчальні заклади та творчі вчителі. Так, учителька-методистка Л. О. Тасенко (загальноосвітній навчальний заклад I-III ступенів № 16, м. Кропивницький), реалізуючи проблему «Використання IКТ на уроках біології як засіб формування інформаційної компетентності учнів», забезпечила широке упровадженням IKT та педагогічного програмного забезпечення у навчальний процес під час навчання біології в умовах роботи основної та старшої школи.

Власний досвід практичного застосування IКТ у навчально-виховному процесі під час вивчення біології в умовах оптимізації навчання для формування інформаційної компетентності учнів, розвитку їх критичного й логічного мислення, пізнавальної активності та творчих здібностей Людмила Олександрівна успішно передає студентам - майбутнім учителям біології під час педагогічної практики на базі творчої лабораторії вчителя, шляхом участі у студентських наукових конференціях, через публікації у педагогічній пресі та консультування студентів. Вона також долучає студентів до апробації методик навчання біології з використанням ІКТ для створення комфортного навчального середовища, формування вмінь і навичок дослідницької й пошукової роботи учнів із сучасними інформаційними ресурсами, поєднання біологічних знань із життєвим досвідом та майбутньою професійною діяльністю.

Практичне вивчення студентами досвіду вчителя-майстра сприяє формуванню вмінь застосування інтерактивної методики навчання біології, забезпеченні диференціації та психологізації навчально-виховного процесу, спрямованих на удосконалення методів, прийомів та засобів формування і контролю знань учнів із біології, розвиток предметних компетентностей, дослідницьких умінь школярів, що забезпечує їх саморозвиток, виробляє навички самоаналізу, самоконтролю та самооцінки.

Студенти-випускники зазначають, що саме практика дала можливість закріпити теоретичні знання і застосовувати їх у педагогічній діяльності; допомагає чітко планувати і проводити уроки і позакласні заходи; сприяла розвитку педагогічного мислення, педагогічної спрямованості, професійних здібностей, умінь і навичок організації навчально-виховного процесу, вмінь спілкуватись із учнями, відстоювати свою точку зору, шукати вихід 3 педагогічних ситуацій; сприяла формуванню професійних значимих якостей особистості вчителя; допомогла адаптуватися і вдосконалюватись в майбутній професії.

Успішній підготовці студентів до творчої педагогічної діяльності сприяє змістовна, цілеспрямована робота в студентських наукових гуртках та проблемних наукових студіях, участь у наукових студентських конференціях, та спільно з викладачами у міжвузівських та всеукраїнських наукових заходах.

Студенти відкриті для сприйняття засад гуманістичної педагогіки, усвідомлюють, що Василь Олександрович досяг визначних успіхів у створенні «Школи радості», написав блискучі педагогічні праці лише завдяки поєднанню величі таланту, надзвичайної працьовитості, виключної цілеспрямованості й любові до людей, дітей та до життя.

Висновки. Закон «Про освіту» визначає іiі метою всебічний розвиток людини як особистості та найвищої цінності суспільства, розвиток іiі талантів, розумових, творчих і фізичних здібностей, формування цінностей і необхідних компетентностей для ії успішної самореалізації, виховання відповідальних громадян, здатних до свідомого суспільного вибору, підготовку кваліфікованих фахівців, задля забезпечення сталого розвитку України та ії європейського вибору. 
Система В. О. Сухомлинського привертає увагу ціннісною спрямованістю на пошану до кожної дитини, розумінням іiі самобутності й унікальності. Під плином вимог сучасного життя вона, безперечно, постійно трансформується. Проте принципова основа залишається майже незмінною. Серед відомих систем виховання вона виокремлюється як «найгуманніша педагогіка», і потребує грунтовного вивчення й використання у процесі реалізації освітніх реформ, насамперед у ході розбудови Нової української школи.

\section{СПИСОК ВИКОРИСТАНОЇ ЛІТРАТУРИ}

1. Концепція «Нова українська школа» [Електронний pecypc]. URL: http://mon.gov.ua/activity/ education/zagalna-serednya/ua-sch-2016 (дата звернення: 20.06.2019).

2. Концепція реалізації державної політики у сфері реформування загальної середньої освіти «Нова українська школа» на період до 2029 року від 14.12.2016 № 988-p. [Електронний ресурс]. URL : http://www.kmu.gov.ua/control/uk/cardnpd?docid= 249613934 (дата звернення: 27.07.2019).

3. Закон України «Про освіту» від 05.09.2017 № 2145-VIII [Електронний ресурс] // Відомості Верховної Ради. - 2017. - № 38-39. - C. 380. URL: https://zakon.rada.gov.ua/laws/show/2145-19/print (дата звернення: 20.06.2019).

УДК 378.14.015.62

DOI: 10.37026/2520-6427-2019-99-3-152-157
4. Калініченко Н. А. Гуманістична спрямованість підготовки майбутніх учителів природничих наук / Н. А. Калініченко // Наукові записки ; ред. кол. : В. Ф. Черкасов, В. В. Радул, Н. С. Савченко та ін. Кропивницький : Код, 2018. Вип. 171. - С. 54-59. (Серія «Педагогічні науки»).

5. Калініченко Н. А. Навчання обдарованих учнів у дидактичній системі Василя Сухомлинського / Н. А. Калініченко // Науковий вісник Миколаївського нац. ун-ту ім. В. О. Сухомлинського. Педагогічні науки : зб. наук. пр. / за ред. Т. Степанової. - 2018. Т. 1. - № 3 (62). - Миколаїв : МНУ імені В. О. Сухомлинського, 2018. - С. 71-76.

6. Сухомлинський В. О. Розмова з молодим директором / В. О. Сухомлинський // Вибрані твори : в 5 т. - К. : Рад. школа, 1976. - Т. 4. -640 с.

7. Сухомлинський В. О. Сто порад учителеві / В. О. Сухомлинський. - К. : Рад. шк., 1988. - 310 с.

8. Сухомлинський В. О. Методика виховання колективу / В. О. Сухомлинський // Вибрані твори : в 5 т. К.: Рад. шк., 1976. - Т. 1. - С. 403-637.

9. Сухомлинський В. О. Павлиська середня школа / В. О. Сухомлинський // Вибрані твори : в 5 т. - К. : Рад. шк., 1977. - Т. 4. - С. 5-390.

Дата надходження до редакиіï: 11.08.2019 p.

Інеса ХМЕЛЯР, кандидатка педагогічних наук, професорка кафедри хіміко-фармацевтичних дисииплін КЗВО «Рівненська медична академія»

Рівненської обласної ради

Оксана МялЮк, кандидатка біологічних наук, завідувачка навчально-методичною лабораторією, викладачка клінічної лабораторної діагностики КЗВО «Рівненська медична академія» Рівненської обласної ради

\section{ФОРМУВАННЯ ДОСЛІДНИЦЬКОЇ КОМПЕТЕНТНОСТІ СТУДЕНТІВ-ЛАБОРАНТІВ}

У статті обтрунтовано підходи до визначення змісту дослідницької компетентності студентів, визначено ефективні форми, методи і засоби ї̈ формування у прочесі викладання навчальної дисципліни «Клінічна лабораторна діагностика». Представлено пріоритетні освітні технології та методи, які не надають готових знань, а спонукають до пошуку, та в яких роль викладача зводиться до функиії тьютора й організатора, щзо сприяє підвищенню самооиінки особистості студента, закладає основи його професійного зростання. 3'ясовано структуру та етапи проведення практичних занять із навчальної дисичпліни «Клінічна лабораторна діагностика».

Ключові слова: дослідницька компетентність, дослідницькі вміння, професійна підготовка майбутніх лаборантів клінічних лабораторій.

В статье обоснованы подходы к определению содержсания исследовательской компетентности студентов, определены эффективные формы, методы и средства ее формирования в прочессе преподавания учебной дисииплинь «Клиническая лабораторная 